\title{
The Study on Moral Education Infiltration into PE Teaching of Universities
}

\author{
Gaosheng Li \\ Public Basic Course Department \\ Wuhan Technology and Business University \\ Wuhan, P.R.China
}

\begin{abstract}
In modern PE teaching, the implementation of moral education has not only become the need of deepening PE reform in universities, and has become the subjective need of renewing today's $P E$ education concept. Since the implementation of curriculum reform, PE teaching has stepped into a new stage. PE education is no longer limited to the platform of educating $\mathrm{PE}$ knowledge, but on this platform it undertakes the task of fostering students' virtues and giving them virtue education when enhancing students' physique. Nowadays, the idea of improving students' physique and promoting the harmonious development of students' body and mind has become an important field of giving students moral education in PE education of all universities.
\end{abstract}

Keywords-PE teaching; moral education infiltration; the harmonious development of body and mind

\section{INTRODUCTION}

Moral education is one of the best tools of students' patriotism education. It can cultivate college students' ideology and morality as well as psychological diathesis, and it plays an important role in improving students' aesthetic quality. $\mathrm{PE}$ education has transferred from the teaching of individual sports to focusing on the ideology of students. In PE classes as well as different matches and games, students' strong mind and perseverance, teamwork spirit, competitiveness and courage are greatly needed. At this time, it is a great chance to cultivate those merits. Therefore, it is necessary to filter the moral education into the PE teaching.

\section{MEANS OF MORAL EdUCATION IN PE TEACHING}

\section{A. Moral Education Based on the Regular Class Rules}

There are many ways of implementing moral education in PE classes, such as class teaching, after-class PE activities, teacher-student relationship and students' own performance. $\mathrm{PE}$ teaching involves a wide range of teaching contents with strong ideology, which is beneficial to implement moral education among college students. PE teachers should implement moral education by connecting the PE textbooks and class regulations, exploring the teaching contents in the textbooks, making a detailed plan of filtering moral education and fixing the corresponding teaching tasks, which conforms to the teaching instructions of $\mathrm{PE}$ and is a necessary process of implementing moral education. Moral education infiltration involves different teaching tasks according to the wide range of PE teaching contents and different characteristics of PE textbooks.

\section{B. Teachers' Involvement into Being Role Models by Explaining}

It is very common that many PE teachers neglect many functions of PE but focus more on the training of PE skills and students' physical quality in teaching activities. Teachers should build up moral teaching concepts and be role models of virtue for students. One of the prerequisites of moral education infiltration is the updating of teachers' teaching concepts. It is important and necessary to bring teachers' subjective initiative into play. Teachers should fully realize the status and importance of moral education in PE teaching. In this process, PE teachers play the roles of the demonstrators of teaching contents. Their moral behaviors and traits will directly influence their students. Therefore, teachers should be strict with themselves in every aspect and impart the merits of values like enthusiasm, optimism, courage, integrity and enterprising spirit to students through their own behaviors. Thus, teachers must need morality to strengthen selfcultivation, be strict with themselves and try to be daily role models of virtue, in which way teachers enlighten the students with their good virtues and win the respect and trust of students. And in this way teachers can build a good image and prestige among students and win students over to further demonstrate the best effect of moral education..

\section{Rich extracurricular PE Activities}

The biggest feature of extracurricular PE activities is that they are not limited to the teaching plan and allow students to voluntarily choose to participate in or develop different forms of PE activities according to students' interests. The best advantage of extracurricular PE activities is that they can conform to students' own character and need to stimulate their interest and initiative. Students' good virtues are formed and developed through concrete practices in a certain social environment. Extracurricular PE activities can help to cultivate students' independence, creation, self-confidence, strong mind and combatant spirit. Moral education in PE teaching must be closely related to the features, contents, and forms of $\mathrm{PE}$ teaching, to prevent moral education from being only written into teaching plan. Moral education filtered into PE 
teaching can also help to strengthen students' ability of telling right from wrong and self-teaching and help to enhance students' discipline and sense of responsibility.

\section{OPTIMIZING THE METHODS OF MORAL EDUCATION}

\section{A. Timing Orientation Method}

Moral education sometimes is no constant. It has the features of being sudden and hidden, which involves us in seizing the chance to filter the moral education in PE teaching. In the real class activities, because of the differences in collective and individual activities, students have different performances and behaviors. Teachers should give students guidance in their language and attitudes and find in time some bad emotions and feelings among students to educate them on purpose. Teachers should lead the students into the right way by giving them the on-the-spot guidance.

\section{B. Target Incentive Method}

Compared to other major courses, one of the nonsubstitutable aspects of PE is the education and guidance of students' volition and character. In teaching process, teachers, making use of increasing the difficulty degrees and setting obstacles, should encourage students to finish the set target to overcome difficulties and guide students to improve their character of dealing with hardships and labors. PE carefully connects interesting aspects and difficulties. After finishing some certain learning tasks, students have to work very hard to overcome some challenges in psychology, physiology and natural phenomena. Through the use of target incentive method, teachers must purposefully guide students to achieve the set goal and finish the set tasks based on their subjective hard work, according to students' individual personalities and abilities. In this way, students' volition and character will be Further Improved.

\section{Focusing on Students' Moral Evaluation}

Any evaluating system can not be without the evaluation of objectiveness and comparativeness. Moral evaluation on students is a basic investigation into students' ideological and moral standards and a way to check the effects of virtue education. Students also care about the objective evaluation given by others. Teachers always improve the timeliness of moral education by connecting PE grades and moral education evaluation. This is a system which plays a guiding role for students based on students' comprehensive quality. In evaluating students, qualitative parameters and quantitive parameters should be closely related to give the PE grades to the students. Thus, students' interest in learning PE and going in for PE activities will be greatly enhanced and the scientific quality of moral education evaluation will be greatly improved.

\section{CONCLUSION}

Based on the analysis of moral education infiltration in PE teaching of universities, the effects of moral education must be highly valued in implementing moral education. Some abstract concepts in moral education contents must be changed into some concrete contents in real PE teaching, which can make moral education become a subject research with some certain learning values. The building of reasonable and scientific evaluation system of moral education makes moral education in schools play a big role in students' virtue education. The task of moral education should be built on ideological construction to improve students' moral quality and integrate physical training into virtue education. Moral education infiltration should be developed into a all-round educational concept in educational system by enriching the importance and interest of moral education in PE teaching and improving the contents of moral education.

\section{REFERENCES}

[1] Cai Jiang, Li Jinghui. Moral Education in PE Teaching of Normal Universities [J]. Journal of Social Science of Jiamusi University. 2000,(6).

[2] Ma Gaizhi. The Analysis of Time and Method of Implementing Moral Education in PE Teaching[J]. The Science Education Article Collects. 2007. (9).

[3] Zhao Xiang, Li Yunqing. Opinions On Moral Education in PE Teaching[J]. Science \& Technology Information. 2007, (15). 